\title{
Performance and Durability of the Zr-Doped CaO Sorbent under Cyclic Carbonation-Decarbonation at Different Operating Parameters
}

\author{
Vyacheslav V. Rodaev * and Svetlana S. Razlivalova
}

check for updates

Citation: Rodaev, V.V.; Razlivalova, S.S. Performance and Durability of the $\mathrm{Zr}$-Doped $\mathrm{CaO}$ Sorbent under Cyclic Carbonation-Decarbonation at Different Operating Parameters. Energies 2021, 14, 4822. https:// doi.org/10.3390/en14164822

Academic Editor: Muhammad Akram

Received: 14 June 2021

Accepted: 5 August 2021

Published: 7 August 2021

Publisher's Note: MDPI stays neutral with regard to jurisdictional claims in published maps and institutional affiliations.

Copyright: (c) 2021 by the authors. Licensee MDPI, Basel, Switzerland. This article is an open access article distributed under the terms and conditions of the Creative Commons Attribution (CC BY) license (https:/ / creativecommons.org/licenses/by/ $4.0 /)$.
Institute for Nanotechnology and Nanomaterials, Derzhavin Tambov State University, Internatsionalnaya Str. 33, 392000 Tambov, Russia; razlivalova8@yandex.ru

* Correspondence: rodaev1980@mail.ru; Tel.: +7-910-6522328; Fax: +7-4752-532680

\begin{abstract}
The effect of cyclic carbonation-decarbonation operating parameters on $\mathrm{Zr}$-doped $\mathrm{CaO}$ sorbent $\mathrm{CO}_{2}$ uptake capacity evolution is examined. It is revealed that the capacity steady state value increases with the decrease in the carbonation temperature, $\mathrm{CO}_{2}$ concentration in the gas flow upon carbonation and with the increase in the heating rate from the carbonation to the decarbonation stages. The rise in decarbonation temperature leads to a dramatic decrease in the sorbent performance. It is found that if carbonation occurs at $630{ }^{\circ} \mathrm{C}$ in the gas flow containing $15 \mathrm{vol} . \% \mathrm{CO}_{2}$ and decarbonation is carried out at $742{ }^{\circ} \mathrm{C}$, the sorbent shows the highest values of the initial and steady state $\mathrm{CO}_{2}$ uptake capacity, namely, $10.7 \mathrm{mmol} / \mathrm{g}$ and $9.4 \mathrm{mmol} / \mathrm{g}$, respectively.
\end{abstract}

Keywords: CaO-based sorbent; high-energy milling; $\mathrm{CO}_{2}$ capture; cyclic carbonation-decarbonation; sorbent sintering

\section{Introduction}

Nowadays, three technologies are considered promising for large-scale post-combustion $\mathrm{CO}_{2}$ capture, namely, amine scrubbing, pressure swing adsorption and calcium looping (CaL) [1-4]. The main disadvantages of amine scrubbing are a significant energy penalty due to solvent regeneration, equipment corrosion, limitation on the operating temperature, solvent loss and accompanied environment impact. The pressure swing adsorption using physical sorbents is characterized by low selectivity, limitations on operating temperature and high operating pressure to achieve high $\mathrm{CO}_{2}$ uptake capacity. Both amine scrubbing and pressure swing adsorption can only be used for $\mathrm{CO}_{2}$ sorption from the flue gas produced during fossil fuel combustion after the flue gas precooling. The use of $\mathrm{CaL}$ to capture $\mathrm{CO}_{2}$ from flue gases was first suggested in 1999 [5]. The CaL process involves the reversible reaction $\mathrm{CaO}+\mathrm{CO}_{2} \leftrightarrow \mathrm{CaCO}_{3}$. $\mathrm{CaO}$ is circulated between two fluidized bed reactors called the carbonator and the calciner. The $\mathrm{CaL}$ process has a number of major advantages: operating at atmospheric pressure and the use of circulating fluidized bed reactors-a mature technology at a large scale, the energy efficiency penalty is relatively small compared to amine scrubbing, the possibility of selective $\mathrm{CO}_{2}$ trapping from hot flue gas, synergy with the existing power plants and cement plants and use of sorbent derived from cheap environmentally benign friendly raw materials (limestone and dolomite) [5-7]. The CaL process is also a promising approach for $\mathrm{CO}_{2}$ utilization since it provides a high-concentrated $\mathrm{CO}_{2}$ stream during decarbonation $[5,6]$.

$\mathrm{CaO}$ is inexpensive and possesses higher $\mathrm{CO}_{2}$ uptake capacity (the maximum value is about $17.9 \mathrm{mmol} / \mathrm{g}$ ) compared to alkaline ceramics (for example, $\mathrm{Li}_{4} \mathrm{SiO}_{4}-8.3 \mathrm{mmol} / \mathrm{g}$, $\mathrm{Li}_{2} \mathrm{ZrO}_{3}-6.5 \mathrm{mmol} / \mathrm{g}$ ) also suitable for $\mathrm{CO}_{2}$ capture at elevated temperatures [4].

The main disadvantage of $\mathrm{CaO}$ is a rapid decline in reactivity under the cyclic carbonation-decarbonation process caused by the following major factors: low Tammann temperature of $\mathrm{CaCO}_{3}$, carbonation process high exothermicity and a big difference in molar volumes of $\mathrm{CaO}\left(16.9 \mathrm{~cm}^{3} / \mathrm{mol}\right)$ and $\mathrm{CaCO}_{3}\left(36.9 \mathrm{~cm}^{3} / \mathrm{mol}\right)$. One of the approaches 
used to improve the cyclic stability of $\mathrm{CaO}$ is the development of $\mathrm{CaO}-$ based synthetic sorbents via incorporation of the dopant into $\mathrm{CaO}$. Inertness to $\mathrm{CO}_{2}$ in the temperature range of the CaL process and high sintering temperature (Tammann temperature) are the criteria for the dopant selection. The dopant acts as a spacer, preventing $\mathrm{CaO} / \mathrm{CaCO}_{3}$ sintering during cyclic carbonation-decarbonation. The sol-gel method, co-precipitation and flame spray pyrolysis are commonly used to fabricate different $\mathrm{CaO}$-based sorbents $[8,9]$ and, in particular, the $\mathrm{Zr}$-doped $\mathrm{CaO}$ sorbents which exhibit superior performance and durability $[10,11]$. These techniques deal with $\mathrm{CaO}$ and the dopant precursors and give rise to nanosized composite sorbents with enhanced $\mathrm{CO}_{2}$ capture performance and cyclic stability. High-energy milling also ensures efficient particle size reduction and effective dispersion, while being easier to implement, thus this method seems to be more promising for the industrial application than the above laboratory methods [12-14]. Moreover, high-energy milling is the most obvious approach to fabricate composite materials from chemically inert components. In [14] we used high-energy co-milling of calcium carbonate and baddeleyite (natural zirconia mineral), followed by heat-treatment of the obtained nanopowder to fabricate $\mathrm{CaO}$ sorbent doped with well-dispersed $\mathrm{CaZrO}_{3}$ nanoparticles to prevent its sintering. The prepared $\mathrm{Zr}$-doped $\mathrm{CaO}$ sorbent was characterized by a high enough steady state $\mathrm{CO}_{2}$ uptake capacity of $8.6 \mathrm{mmol} / \mathrm{g}$ under a multi-cycle carbonation-decarbonation process. The Tammann temperature of $\mathrm{CaZrO}_{3}$ is $1218^{\circ} \mathrm{C}$ [11]. We used natural zirconia since it is much cheaper than chemically synthesized zirconia and its precursors. Previously, high-energy milling has already been successfully applied to baddeleyite to produce engineering-nanostructured zirconia ceramic with competitive mechanical properties [15].

The synthesis method, the nature of the dopant and the dopant concentration in the sorbent are usually considered as the main factors affecting performance and durability of the developed $\mathrm{CaO}-$ based sorbents. At the same time, due attention is not paid to the effect of the cyclic carbonation-decarbonation operating parameters on the performance of sorbents, although it is important in terms of prospects and limitations to their practical application.

The aim of this work is to investigate the effect of cyclic carbonation-decarbonation operating parameters on the performance of $\mathrm{CaO}$-based sorbents promoted with chemically inert and heat-resistant dopants on the example of the $\mathrm{Zr}$-doped $\mathrm{CaO}$ sorbent produced using high-energy milling. Such operating parameters as carbonation and decarbonation temperatures, $\mathrm{CO}_{2}$ concentration in the gas flow upon carbonation and the heating rate from the carbonation to the decarbonation stages were varied.

\section{Materials and Methods}

Baddeleyite concentrate powder ( $5 \mu \mathrm{m}, 99.3 \%$, Kovdorsky GOK, Kovdor, Russia) and $\mathrm{CaCO}_{3}$ powder (99.5\%, Sigma-Aldrich, Saint Louis, MO, USA) were mechanically mixed to prepare the composite powder with the $\mathrm{Zr} / \mathrm{Ca}$ molar ratio of 2:10. High-energy milling of the composite powder using distilled water was performed on a planetary mill Pulverisette 7 Premium Line (Fritsch, Idar-Oberstein, Germany) during $5 \mathrm{~h}$. The resulting product was dried in air at $80^{\circ} \mathrm{C}$ for $24 \mathrm{~h}$ in an OV-11 oven (Jeio Tech Co., Ltd., Seoul, Korea).

The thermal analyzer EXSTAR TG/DTA7200 (SII Nano Technology, Tokyo, Japan) was used to measure $\mathrm{CO}_{2}$ uptake capacity of the $\mathrm{Zr}$-doped $\mathrm{CaO}$ sorbent. Before measurements, the sorbent was activated by heat treatment under $\mathrm{N}_{2}$ for $\mathrm{CaCO}_{3}$ decomposition. Then, the sorbent was cooled to the target carbonation temperature at a rate of $10^{\circ} \mathrm{C} / \mathrm{min}$ and held for $30 \mathrm{~min}$ in the gaseous stream of $100 \mathrm{~mL} / \mathrm{min}$. The flow of $\mathrm{CO}_{2}$ and $\mathrm{N}_{2}$ contained $15,30,50$ or 100 vol. $\% \mathrm{CO}_{2}$. After carbonation, the sorbent was heated up to the target decarbonation temperature at a rate of $20^{\circ} \mathrm{C} / \mathrm{min}$, and held for 20 min under a $\mathrm{N}_{2}$ flow of $100 \mathrm{~mL} / \mathrm{min}$. The carbonation-decarbonation cycle was repeated 25 times. For each cycle, the $\mathrm{CO}_{2}$ uptake capacity $(\mathrm{mmol} / \mathrm{g})$ of the sorbent was determined as the amount of captured $\mathrm{CO}_{2}$ divided by the sorbent weight before carbonation. The target carbonation and decarbonation temperatures were determined using differential thermogravimetric (DTG) analysis as temperatures when carbonation and decarbonation rates were maximal. 
DTG analysis was performed in a $\mathrm{N}_{2}$ flow when the sorbent was heated from 500 to $900{ }^{\circ} \mathrm{C}$, and in the flow of $\mathrm{CO}_{2}$ and $\mathrm{N}_{2}$ with $15,30,50$ or $100 \mathrm{vol} . \% \mathrm{CO}_{2}$ when the sorbent was cooled from 900 to $500{ }^{\circ} \mathrm{C}$.

The specific surface area $\left(S_{\mathrm{BET}}\right)$ of the $\mathrm{Zr}$-doped $\mathrm{CaO}$ sorbent as microstructure degradation characteristic was measured by nitrogen adsorption at $-196^{\circ} \mathrm{C}$ in a relative pressure range of 0.05-0.35 with a gas sorption analyzer Autosorb iQ-C (Quantachrome Instruments, Boynton Beach, FL, USA) using the Brunauer-Emmett-Teller (BET) method. All the samples were degassed under vacuum at $300^{\circ} \mathrm{C}$ for $3 \mathrm{~h}$ before BET analysis.

\section{Results and Discussion}

According to DTG analysis, the increase in $\mathrm{CO}_{2}$ concentration in the gas at the sorbent carbonation stage leads to a rise in both carbonation and decarbonation effective temperatures (Figure 1). The positions of the carbonation and decarbonation rate peaks are shifted toward higher temperatures and the peaks become narrower (Table 1).
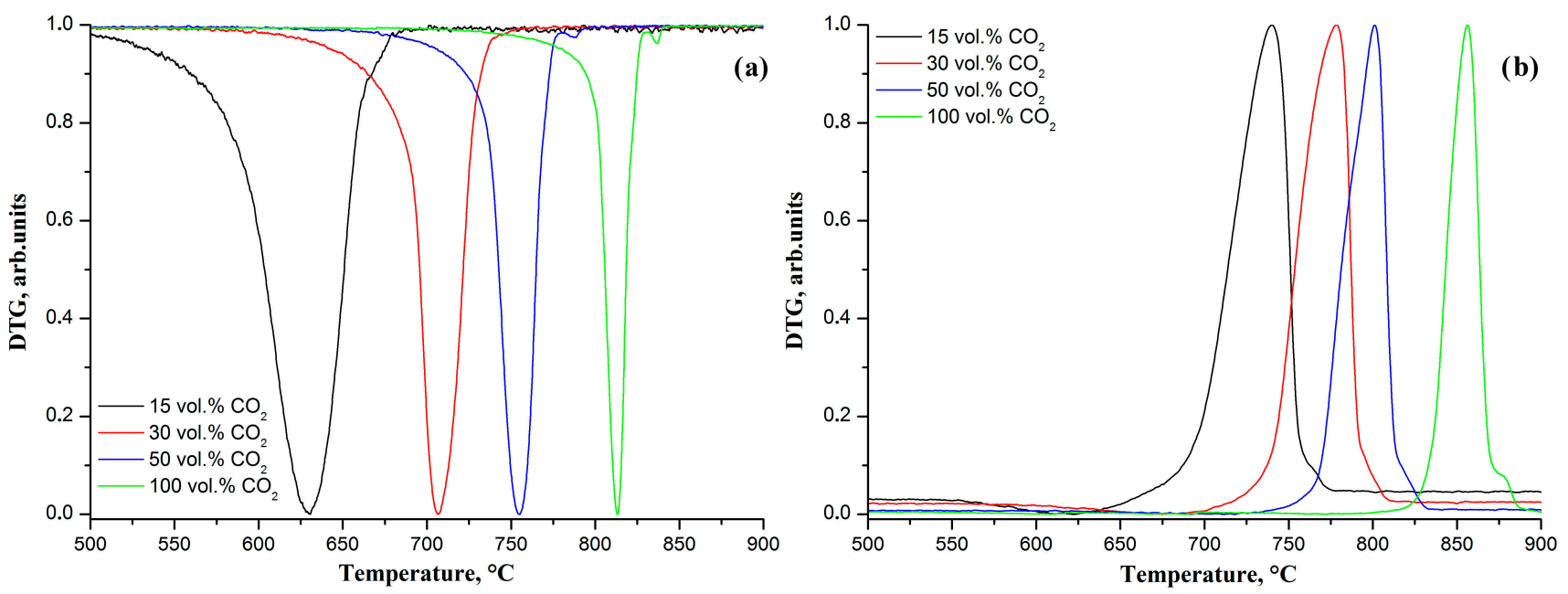

Figure 1. Normalized DTG signals (a) during the sorbent carbonation at different $\mathrm{CO}_{2}$ concentrations in the gas flow; (b) during the sorbent decarbonation if different $\mathrm{CO}_{2}$ concentrations are used at the carbonation stage.

Table 1. The carbonation and decarbonation rates peaks characteristics.

\begin{tabular}{|c|c|c|c|c|}
\hline \multirow{2}{*}{$\begin{array}{l}\mathrm{CO}_{2} \text { Concentrations in the Gas } \\
\text { Flow during Carbonation, vol.\% }\end{array}$} & \multicolumn{2}{|c|}{ Carbonation Rate Peak } & \multicolumn{2}{|c|}{ Decarbonation Rate Peak } \\
\hline & Position $T,{ }^{\circ} \mathrm{C}$ & $\begin{array}{l}\text { Peak width at Half } \\
\text { Height } \Delta T,{ }^{\circ} \mathrm{C}\end{array}$ & Position $T,{ }^{\circ} \mathrm{C}$ & $\begin{array}{c}\text { Peak Width at Half } \\
\text { Height } \Delta T,{ }^{\circ} \mathrm{C}\end{array}$ \\
\hline 15 & 630 & 48 & 742 & 37 \\
\hline 30 & 707 & 26 & 779 & 34 \\
\hline 50 & 755 & 22 & 803 & 27 \\
\hline 100 & 813 & 14 & 857 & 21 \\
\hline
\end{tabular}

The half-height width of the carbonation and decarbonation rate peaks can be considered as the temperature ranges in which the sorbent performs best during carbonation and decarbonation. Table 1 shows that the ranges of operating temperatures of the sorbent depend on $\mathrm{CO}_{2}$ concentration in the gas flow during carbonation.

The effect of cyclic carbonation-decarbonation on the sorbent $\mathrm{CO}_{2}$ uptake capacity at different $\mathrm{CO}_{2}$ concentrations in the gas flow during carbonation is shown in Figure 2. The carbonation and decarbonation are performed at the temperatures indicated in Table 1 . It is observed that the initial $\mathrm{CO}_{2}$ uptake capacity of the sorbent slightly decreases from 10.7 to $10.2 \mathrm{mmol} / \mathrm{g}$ with the $\mathrm{CO}_{2}$ concentration increase from 15 to $100 \mathrm{vol} . \%$. Stoichiometric capacity of the sorbent is about $12.4 \mathrm{mmol} / \mathrm{g}$. The $\mathrm{CO}_{2}$ uptake capacity of the sorbent decreases with a rise in the cycle number attaining $9.2,8.9,8.2$ and $7.7 \mathrm{mmol} / \mathrm{g}$ in the 25th cycle 
at 15, 30, 50 and 100 vol. $\% \mathrm{CO}_{2}$, respectively. The drop in the capacity value increases from 1.5 to $2.5 \mathrm{mmol} / \mathrm{g}$ with a rise in $\mathrm{CO}_{2}$ concentration from 15 to $100 \mathrm{vol} . \%$. The dependence of the sorbent $\mathrm{CO}_{2}$ uptake capacity on the number of carbonation-decarbonation cycles attains saturation near the 25th cycle if the sorbent is carbonated in the atmosphere containing 15 vol. $\% \mathrm{CO}_{2}$. Thus, it can be concluded that the sorbent is more resistant to cyclic carbonation-decarbonation if carbonation occurs at lower $\mathrm{CO}_{2}$ concentrations and low temperatures. In further experiments, carbonation is performed at $630^{\circ} \mathrm{C}$ in the gas flow containing 15 vol. $\% \mathrm{CO}_{2}$ because such a concentration corresponds to the typical $\mathrm{CO}_{2}$ content in the exhaust gases of coal-fired power plants and the indicated carbonation temperature corresponds to the average exhaust gases temperature [16].

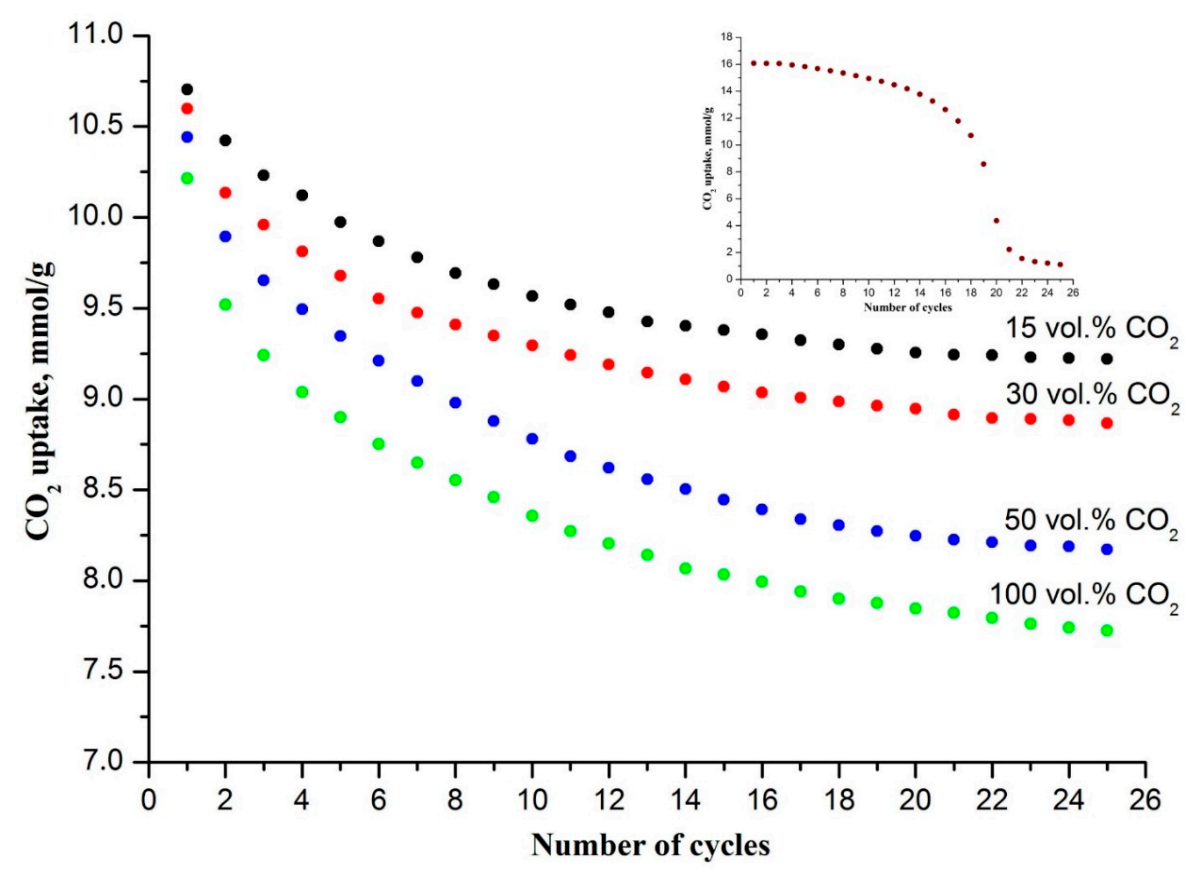

Figure 2. The dependencies of the sorbent $\mathrm{CO}_{2}$ uptake capacity on the number of carbonationdecarbonation cycles at different $\mathrm{CO}_{2}$ concentrations in the gas flow upon carbonation. The insert shows the dependence of zirconium-undoped sorbent $\mathrm{CO}_{2}$ uptake capacity on the number of carbonation-calcination cycles at 15 vol. $\% \mathrm{CO}_{2}$ in the gas flow upon carbonation.

In terms of steady state $\mathrm{CO}_{2}$ uptake capacity, the studied sorbent is not inferior to $\mathrm{CaO}$ sorbents doped with $\mathrm{CaZrO}_{3}$ previously prepared by co-precipitation $(9.6 \mathrm{mmol} / \mathrm{g})$ [17], a sol-gel auto-combustion synthesis $(9.2 \mathrm{mmol} / \mathrm{g})$ [18] and the surfactant template/ultrasoundassisted technique $(3.4 \mathrm{mmol} / \mathrm{g})$ [19].

It should be noted that if the sorbent is undoped, it shows higher initial $\mathrm{CO}_{2}$ uptake capacity than the $\mathrm{Zr}$-doped one on a weight basis, due to the inertness of the dopant to $\mathrm{CO}_{2}$. However, the capacity of pure $\mathrm{CaO}$ sorbent decreases dramatically by the 25 th cycle (insert in Figure 2).

It has been revealed that both cyclic carbonation-decarbonation and the rise in $\mathrm{CO}_{2}$ concentration in the gas flow at carbonation lead to a decrease in the sorbent-specific surface area (Table 2). After 25 carbonation-decarbonation cycles, the specific surface area decreases by $3.7,7.4,15.2$ and $20.3 \%$ in relation to the virgin sorbent-specific surface area value of $21.7 \mathrm{~m}^{2} / \mathrm{g}$ if carbonation occurs in the atmosphere containing $15,30,50$ or 100 vol. $\% \mathrm{CO}_{2}$, respectively. 
Table 2. The sorbent-specific surface area after the 25th carbonation-decarbonation cycle at different $\mathrm{CO}_{2}$ concentrations in the gas flow during carbonation.

\begin{tabular}{cc}
\hline $\mathrm{CO}_{\mathbf{2}}$ Concentration in the Gas Flow, vol. $\%$ & $\mathbf{S}_{\mathrm{BET}}, \mathbf{~}^{\mathbf{2}} \mathbf{g}$ \\
\hline 15 & 20.9 \\
30 & 20.1 \\
50 & 18.4 \\
100 & 17.3 \\
\hline
\end{tabular}

The Tammann temperature of $\mathrm{CaCO}_{3}$ is $533{ }^{\circ} \mathrm{C}$ [11], which is much lower than the used carbonation temperatures (Table 1). Therefore, $\mathrm{CaCO}_{3}$ forming during carbonation gets sintered, which has a negative effect on the $\mathrm{CO}_{2}$ uptake capacity of $\mathrm{CaO}$. Previously, we found that dopant nanoparticles homogeneously dispersed in the tested sorbent separate the sorbent particles from each other, thus hindering $\mathrm{CaCO}_{3}$ sintering that slows down the $\mathrm{CaO}$ particle growth and the sorbent porosity reduction during cyclic carbonationdecarbonation [14]. As a result, the decrease in the $\mathrm{CO}_{2}$ uptake capacity of the $\mathrm{CaO}$ sorbent functionalized by dopant nanoparticles is less pronounced with the increasing number of cycles than the capacity of pure $\mathrm{CaO}$ sorbent (Figure 2).

The rise in $\mathrm{CO}_{2}$ concentration in the gas flow increases the carbonation intensity that results in densification of the $\mathrm{CaCO}_{3}$ layer forming on the surface of $\mathrm{CaO}$ particles, which impedes the penetration of $\mathrm{CO}_{2}$ deep into the $\mathrm{CaO}$ particles; therefore, a higher carbonation temperature is required to provide $\mathrm{CO}_{2}$ penetration through the product layer, and a higher decarbonation temperature is also required to decompose the dense well-sintered product layer. The $\mathrm{CaCO}_{3}$ sintering results in $\mathrm{CaO}$ particles' growth with each subsequent carbonation-decarbonation cycle. The higher the $\mathrm{CO}_{2}$ concentration, the more intense the $\mathrm{CaO}$ particles' growth at carbonation, which is confirmed by the specific surface area measurements (Table 2).

In [20], it was reported that at the product layer thickness of about $50 \mathrm{~nm}$, an extremely slow diffusion-controlled carbonation stage replaces the fast initial chemical reactioncontrolled one. Since the $\mathrm{CaCO}_{3}$ layer seals $\mathrm{CaO}$ inside the sorbent particle and makes it inaccessible for carbonation, the amount of non-reacted $\mathrm{CaO}$ increases with each subsequent cycle, due to the sorbent particles' growth. It explains the sorbent $\mathrm{CO}_{2}$ uptake capacity degradation during cycling (Figure 2). The intensive carbonation induced by a high $\mathrm{CO}_{2}$ concentration promotes the capacity reduction.

The influence of different decarbonation temperatures on the sorbent $\mathrm{CO}_{2}$ uptake capacity has been tested too (Figure 3). The carbonation is performed in the gas flow containing 15 vol. $\% \mathrm{CO}_{2}$ at $630{ }^{\circ} \mathrm{C}$ (Table 1). The rise in the decarbonation temperature induces a larger drop in $\mathrm{CO}_{2}$ uptake capacity after the 1st decarbonation. Moreover, at a higher decarbonation temperature the decrease in the $\mathrm{CO}_{2}$ uptake capacity is more notable with each increasing cycle number. In the 25th cycle, the $\mathrm{CO}_{2}$ uptake capacity value attains 9.2, 7.6 and $4.5 \mathrm{mmol} / \mathrm{g}$ at decarbonation temperatures of 742,900 and $1000{ }^{\circ} \mathrm{C}$, respectively. The initial $\mathrm{CO}_{2}$ uptake capacity of the sorbent is $10.7 \mathrm{mmol} / \mathrm{g}$ for the given carbonation parameters. The rise in the decarbonation temperature also results in the sorbent-specific surface area decrease (Table 3). After 25 carbonation-decarbonation cycles, the sorbent-specific surface area decreases by $3.7,21.2$ and $53.5 \%$ in relation to the virgin sorbent-specific surface area value of $21.7 \mathrm{~m}^{2} / \mathrm{g}$. It indicates that the increase in the decarbonation temperature stimulates the $\mathrm{CaO}$ particles' growth.

The decarbonation temperature also affects the carbonation kinetics of the sorbent (insert in Figure 3). It is revealed that the time to attain $90 \%$ of the maximum capacity value in the cycle increases with the rise in the decarbonation temperature. The chemical reaction-controlled stage becomes shorter and slower, and the diffusion-controlled stage becomes longer and starts earlier. 


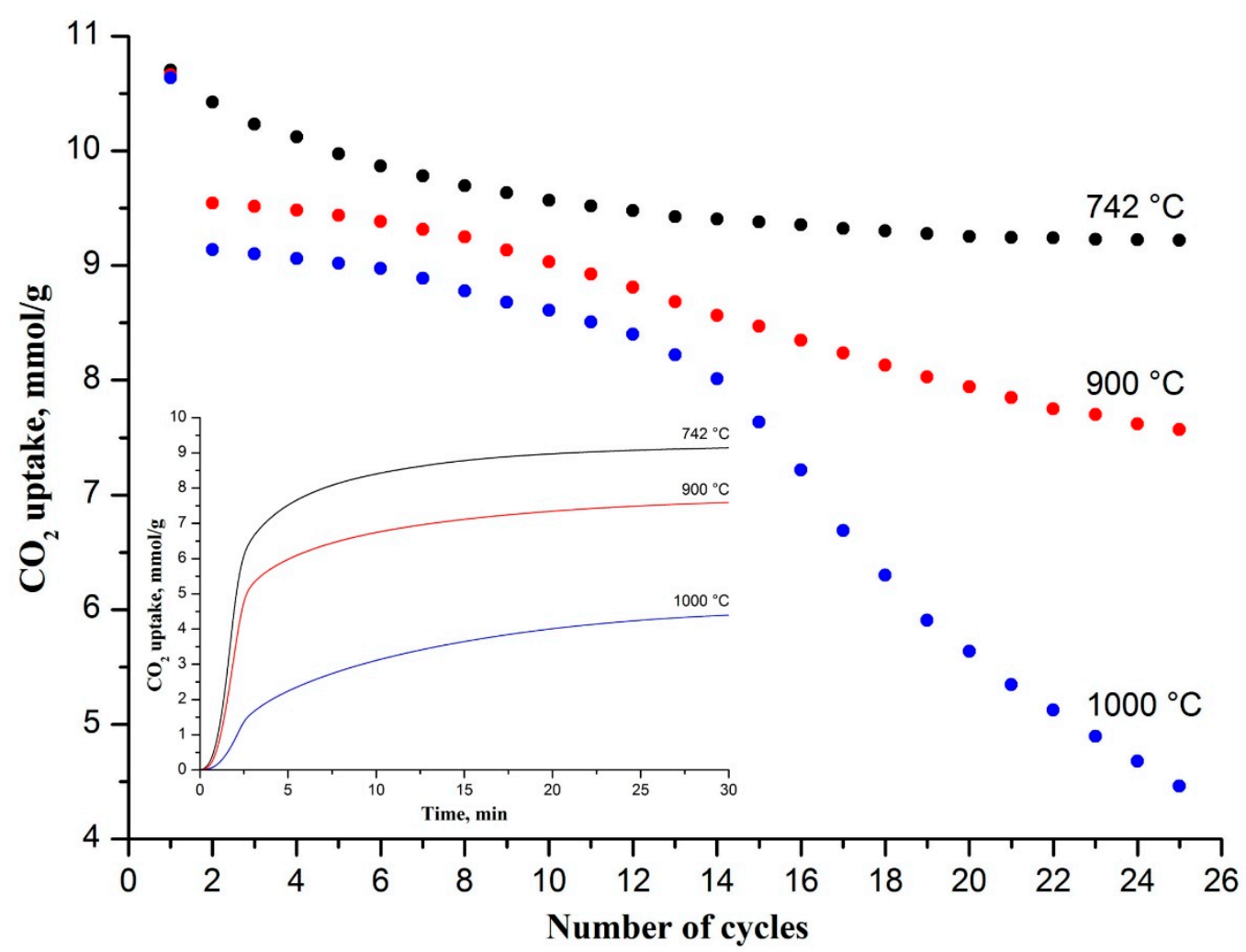

Figure 3. $\mathrm{CO}_{2}$ uptake capacity evolution of the sorbent over cyclic carbonation-decarbonation at different decarbonation temperatures. The carbonation is performed in the gas flow containing 15 vol. $\% \mathrm{CO}_{2}$ at $630{ }^{\circ} \mathrm{C}$. The insert shows the carbonation profiles of the 25 th cycle at different decarbonation temperatures.

Table 3. The sorbent-specific surface area after the 25th carbonation-decarbonation cycle at different decarbonation temperatures.

\begin{tabular}{cc}
\hline Decarbonation Temperature, ${ }^{\circ} \mathbf{C}$ & $\mathbf{S}_{\text {BET }}, \mathbf{~ m}^{2} / \mathbf{g}$ \\
\hline 742 & 20.9 \\
900 & 17.1 \\
1000 & 10.1 \\
\hline
\end{tabular}

$\mathrm{CaCO}_{3}$ sintering occurs during carbonation, heating up to the decarbonation temperature and upon decarbonation. The Tammann temperature of $\mathrm{CaO}$ is $1154^{\circ} \mathrm{C}$ [11], which is much higher than the used carbonation temperatures. Therefore, $\mathrm{CaO}$ sintering does not occur at carbonation. At a low decarbonation temperature, $\mathrm{CaO}$ particle growth is provided only by $\mathrm{CaCO}_{3}$ sintering. The intensity of $\mathrm{CaCO}_{3}$ sintering can be reduced, for instance, by increasing the heating rate from the carbonation to the decarbonation stages that decrease $\mathrm{CaCO}_{3}$ residence time at high temperatures. It is revealed that the sorbent $\mathrm{CO}_{2}$ uptake capacity decreases less with the rise in the cycle number and reaches a stable value earlier if the heating rate is increased (Figure 4). In the 25th carbonation-decarbonation cycle, the difference in capacity values is $3.6 \%$ due to a change in the heating rate from 10 to $40{ }^{\circ} \mathrm{C} / \mathrm{min}$.

An increase in the decarbonation temperature leads to $\mathrm{CaCO}_{3}$ sintering intensification due to heating to a higher temperature. Moreover, when the decarbonation temperature approaches $1154{ }^{\circ} \mathrm{C}$ it leads to the start of $\mathrm{CaO}$ sintering with partial sintering of $\mathrm{CaO}$ particles that additionally promotes $\mathrm{CaO}$ particles growth during decarbonation. 


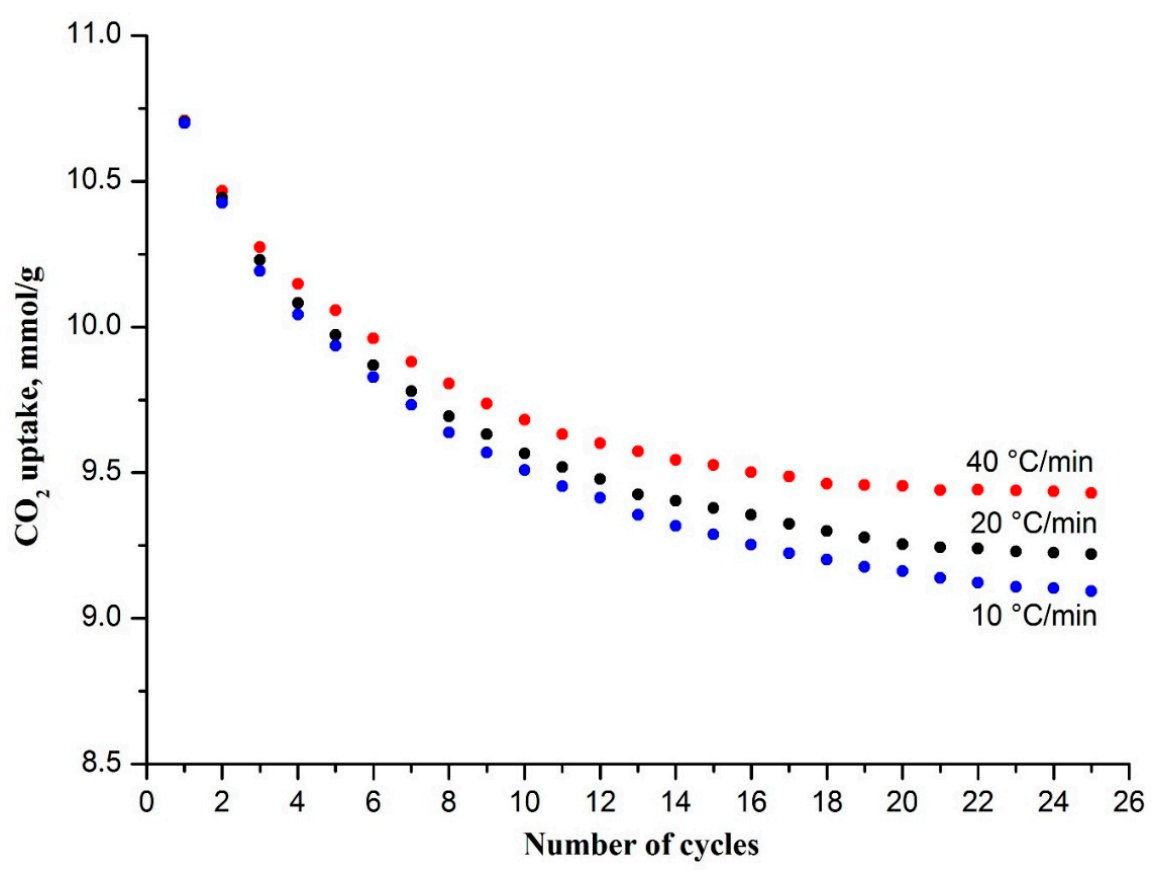

Figure 4. $\mathrm{CO}_{2}$ uptake capacity evolution of the sorbent over cyclic carbonation-decarbonation at different heating rates. The carbonation is performed in the gas flow containing $15 \mathrm{vol} \% \mathrm{CO}_{2}$ at $630{ }^{\circ} \mathrm{C}$.

The rise in the $\mathrm{CaO}$ particles size decreases the sorbent-specific surface area with the decarbonation temperature increase (Table 3). It indicates that the barrier function of the dopant nanoparticles decreases with an increase in the decarbonation temperature due to diffusion intensification promoting the sorbent sintering. A similar effect was observed in [21], where $\mathrm{Nd}_{2} \mathrm{O}_{3}$ nanoparticles were used as spacers instead of $\mathrm{CaZrO}_{3}$ nanoparticles.

$\mathrm{CaO}$ sintering hampers $\mathrm{CO}_{2}$ access to the reaction centers due to gas transport channels blocking. Thus, the amount of trapped unreacting $\mathrm{CaO}$ increases with each subsequent decarbonation. It results in the sorbent $\mathrm{CO}_{2}$ uptake capacity reduction upon cyclic carbonation-decarbonation. Wherein the sorbent $\mathrm{CO}_{2}$ uptake capacity reduction is greater, the higher the decarbonation temperature (Figure 3). The increased $\mathrm{CaO}$ particle size and hindered $\mathrm{CO}_{2}$ penetration deep into the $\mathrm{CaO}$ particles makes a diffusion-controlled mechanism of carbonation dominant when decarbonation occurs at high temperatures (insert in Figure 3).

\section{Conclusions}

It is revealed that the performance of the $\mathrm{Zr}$-doped $\mathrm{CaO}$ sorbent increases with the decrease in the carbonation temperature, $\mathrm{CO}_{2}$ concentration in the gas flow upon carbonation and with the increase in the heating rate from the carbonation to the decarbonation stages. Contrarily, the performance of the sorbent decreases with the rise in the decarbonation temperature. These operating parameters influence the intensity of sorbent sintering, which in turn affects the sorbent $\mathrm{CO}_{2}$ uptake capacity during the cyclic carbonation-decarbonation process. It is found that when carbonation occurs at $630{ }^{\circ} \mathrm{C}$ in the gas flow containing 15 vol. $\% \mathrm{CO}_{2}$ and decarbonation is carried out at $742{ }^{\circ} \mathrm{C}$, the sorbent shows the highest values of the initial and steady state $\mathrm{CO}_{2}$ uptake capacity, namely, $10.7 \mathrm{mmol} / \mathrm{g}$ and $9.4 \mathrm{mmol} / \mathrm{g}$, respectively. At the decarbonation temperature of $900{ }^{\circ} \mathrm{C}$, which is the typical decarbonation temperature for the CaL process, the capacity steady state value decreases to $7.6 \mathrm{mmol} / \mathrm{g}$.

It can be proposed that variations in the carbonation and decarbonation temperatures, $\mathrm{CO}_{2}$ concentration in the gas flow upon carbonation and the heating rate from the carbonation to the decarbonation stages might have a similar effect on the performance of all 
CaO-based sorbents promoted with chemically inert and heat-resistant dopants, regardless of their fabrication method due to the similar operating principle of such sorbents.

Author Contributions: V.V.R.: investigation, writing—original draft preparation, editing; S.S.R.investigation. All authors have read and agreed to the published version of the manuscript.

Funding: The reported study was funded by Russian Foundation for Basic Research (RFBR) according to the research project No. 18-29-12015 and partially supported by the Ministry of Science and Higher Education of the Russian Federation in the frame work of agreement No. 075-15-2021-709.

Institutional Review Board Statement: Not applicable.

Informed Consent Statement: Not applicable.

Data Availability Statement: All data included in this study are available upon request from the corresponding author.

Conflicts of Interest: The authors declare no conflict of interest.

\section{References}

1. Anwar, M.; Fayyaz, A.; Sohail, N.; Khokhar, M.; Baqar, M.; Khan, W.; Rasool, K.; Rehan, M.; Nizami, A. CO 2 capture and storage: A way forward for sustainable environment. J. Environ. Manag. 2018, 226, 131-144. [CrossRef] [PubMed]

2. Koytsoumpa, E.I.; Bergins, C.; Kakaras, E. The $\mathrm{CO}_{2}$ economy: Review of $\mathrm{CO}_{2}$ capture and reuse technologies. J. Supercrit. Fluids 2018, 132, 3-16. [CrossRef]

3. Riboldi, L.; Bolland, O. Overview on Pressure Swing Adsorption (PSA) as $\mathrm{CO}_{2}$ Capture Technology: State-of-the-Art, Limits and Potentials. Energy Procedia 2017, 114, 2390-2400. [CrossRef]

4. Bhatta, L.K.G.; Subramanyam, S.; Chengala, M.D.; Olivera, S.; Venkatesh, K. Progress in hydrotalcite like compounds and metal-based oxides for $\mathrm{CO}_{2}$ capture: A review. J. Clean. Prod. 2015, 103, 171-196. [CrossRef]

5. Dean, C.; Blamey, J.; Florin, N.; Al-Jeboori, M.; Fennell, P. The calcium looping cycle for $\mathrm{CO}_{2}$ capture from power generation, cement manufacture and hydrogen production. Chem. Eng. Res. Des. 2011, 89, 836-855. [CrossRef]

6. Tilak, P.; El-Halwagi, M.M. Process integration of Calcium Looping with industrial plants for monetizing $\mathrm{CO}_{2}$ into value-added products. Carbon Resour. Convers. 2018, 1, 191-199. [CrossRef]

7. Coppola, A.; Scala, F. A Preliminary techno-economic analysis on the calcium looping process with simultaneous capture of $\mathrm{CO}_{2}$ and $\mathrm{SO}_{2}$ from a coal-based combustion power plant. Energies 2020, 13, 2176. [CrossRef]

8. Sun, H.; Wu, C.; Shen, B.; Zhang, X.; Zhang, Y.; Huang, J. Progress in the development and application of CaO-based adsor-bents for $\mathrm{CO}_{2}$ capture-A review. Mater. Today Sustain. 2018, 1-2, 1-27. [CrossRef]

9. $\mathrm{Hu}, \mathrm{Y} . ; \mathrm{Lu}, \mathrm{H}$.; Liu, W.; Yang, Y.; Li, H. Incorporation of $\mathrm{CaO}$ into inert supports for enhanced $\mathrm{CO}_{2}$ capture: A review. Chem. Eng. J. 2020, 396, 125253. [CrossRef]

10. Lu, H.; Khan, A.; Pratsinis, S.E.; Smirniotis, P.G. Flame-made durable doped-CaO nanosorbents for $\mathrm{CO}_{2}$ capture. Energy Fuels 2009, 23, 1093-1100. [CrossRef]

11. Courson, C.; Gallucci, K. CaO-based high-temperature $\mathrm{CO}_{2}$ sorbents. In Precombustion Carbon Dioxide Capture Materials; Wang, Q., Ed.; Royal Society of Chemistry: London, UK, 2018; pp. 144-237.

12. Benitez-Guerrero, M.; Valverde, J.M.; Perejon, A.; Sanchez-Jimenez, P.E.; Perez-Maqueda, L.A. Effect of milling mechanism on the $\mathrm{CO}_{2}$ capture performance of limestone in the Calcium Looping process. Chem. Eng. J. 2018, 346, 549-556. [CrossRef]

13. Sayyah, M.; Lu, Y.; Masel, R.I.; Suslick, K.S. Mechanical activation of CaO-based adsorbents for $\mathrm{CO}_{2}$ Capture. ChemSusChem 2013, 6, 193-198. [CrossRef] [PubMed]

14. Rodaev, V.V.; Razlivalova, S.S. The Zr-Doped $\mathrm{CaO} \mathrm{CO}_{2}$ Sorbent Fabricated by Wet High-Energy Milling. Energies 2020, 13, 4110. [CrossRef]

15. Rodaev, V.V.; Zhigachev, A.O.; Korenkov, V.V.; Golovin, Y.I. Spherical engineering Ca-TZP ceramics made from baddeleyite: Fabrication, structure and mechanical properties. Mater. Sci. Eng. A 2018, 730, 363-366. [CrossRef]

16. Wang, Y.; Zhao, L.; Otto, A.; Robinius, M.; Stolten, D. A Review of Post-combustion $\mathrm{CO}_{2}$ Capture Technologies from Coal-fired Power Plants. Energy Procedia 2017, 114, 650-665. [CrossRef]

17. Soleimanisalim, A.H.; Sedghkerdar, M.H.; Karami, D.; Mahinpey, N. Effects of second metal oxides on zirconia-stabilized Ca-based sorbent for sorption/catalyst integrated gasification. J. Environ. Chem. Eng. 2017, 5, 1281-1288. [CrossRef]

18. Antzara, A.; Heracleous, E.; Lemonidou, A.A. Improving the stability of synthetic CaO-based $\mathrm{CO}_{2}$ sorbents by structural promoters. Appl. Energy 2015, 156, 331-343. [CrossRef]

19. Radfarnia, H.R.; Iliuta, M.C. Development of Zirconium-Stabilized Calcium Oxide Absorbent for Cyclic High-Temperature $\mathrm{CO}_{2}$ Capture. Ind. Eng. Chem. Res. 2012, 51, 10390-10398. [CrossRef] 
20. Alvarez, D.; Abanades, J.C. Determination of the critical product layer thickness in the reaction of $\mathrm{CaO}_{\text {with }} \mathrm{CO}_{2}$. Ind. Eng. Chem. Res. 2005, 44, 5608-5615. [CrossRef]

21. Hu, Y.; Liu, W.; Sun, J.; Li, M.; Yang, X.; Zhang, Y.; Xu, M. Incorporation of $\mathrm{CaO}$ into novel $\mathrm{Nd}_{2} \mathrm{O}_{3}$ inert solid support for high temperature $\mathrm{CO}_{2}$ capture. Chem. Eng. J. 2015, 273, 333-343. [CrossRef] 